\title{
Phases and Dynamics of the Social Movement Process in Indonesia: A Case Study on LAPINDO Mudflow Disaster Victims against the Government
}

\section{Oman Sukmana}

Departement of Social Work, Faculty of Social and Political Sciences, University of Muhammadiyah Malang, Indonesia

oman@umm.ac.id

\begin{abstract}
This study focused on mapping the phases and dynamics of the social movement process of Lapindo mudflow disaster victims in Indonesia. This study was analyzed by using a qualitative. The subject of the study was determined by purposive sampling in which all elements involved in the social movement of mudflow disaster victims. The data were collected by using in-depth interview, observation, FGD, and documentation. The stages of the analysis process involved data reduction, data presentation, and drawing conclusion. The results of the study indicated that the social movements were mapped into three phases: (1) the period of the emergence of the pre-social movement ideas; (2) the period of stabilization and consolidation of the social movements; and (3) the period of the social movement decline. Meanwhile, the dynamics of the social movements of Lapindo mudflow were based on three aspects: (1) political opportunity; (2) mobilizing structure, and (3) cultural framings.
\end{abstract}

Keywords

social movement; phases; dynamics; disaster victims; mudflow disaster

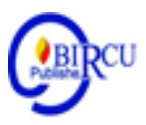

\section{Introduction}

In many countries, such as Europe and the United States of America, social movements emerge as a response towards particular issues regarding anti-racism, anti-nuclearism, disarmament, feminism, environmentalism, regionalism and ethnicity, civil libertarianism, freedom, and peace (Singh, 2001). In the third world, a social movement is indirectly associated with a mainstream approach engineered by several countries through development programs. However, the development programs are perceived by civil society as a reason for economic problems, ecological crisis, and social misery (Fakih, 2010). Meanwhile, (Triwibowo, 2006) pointed out that a social movement is highly related to an organization or civic movement in supporting or opposing particular policy towards social changes. Klandermans (Quah \& Sales, 2000) states that a social movement is a collective movement by certain groups with the same vision and solidarity encountering interaction process continuously against opposition or authorized stakeholder. According to Singh (2001), a social movement expresses social collective attempts to demand both equality and justice which reflect social identity, struggle, and culture. Thus, a social movement is deeply associated with resistance dimension or collective opposition.

In the case of Indonesia, a social movement emerges as an attempt or reaction of certain groups or people against governmental hegemony and domination. Particularly, there are three pillars of power in arranging the social life, namely political power, corporate power, and social power which further yield a social movement. The correlation among them is considered a balance (Damsar, 2010). In certain cases, however, the correlation among these three pillars does not work properly as it creates a submissive element (Budi, 2009). The 
propensity of dominated practices emerges due to a strong relationship between political power and corporate power which create injustice and inequality among the civil society.

Tarrow (2008) states that a social movement is a collective movement created by certain groups with the same vision and solidarity encountering an interaction process continuously against opposition or authorized stakeholder. The elaboration of his statement stated as follows: (1) a movement is an act of resistance towards elite and authorized groups; (2) a movement is conducted on behalf of the same claims towards those groups; (3) an action or movement is based on solidarity and collective identity; and (4) to pursue a collective movement, the resistance is converted into a social movement.

According to Singh (2001), a social movement is a civic attempt which collectively demand social equity and justice reflecting social struggles to protect cultural identities and heritage. Mainly, a social movement becomes a universal power deriving from an institution and historical action in the civic society. Therefore, a social movement emerge not only in the life of the civic society, but also conflict, misery, domination, freedom, and social justice aspects. Furthermore, Singh states that if the imbalance situation and social domination are continuously maintained by a certain social institution, those things will create a critical situation where resistance, rejection, and insurrection cannot be avoided. For him, social structures are conceptualized as a platform for the dominated group and social collectives.

According to Wahlstrom \& Peterson (2006), the objectives of contentious politics are also to diversify international agencies and intra-governmental organisations, as well as economic actors, national and multinational corporations and enterprises, industrial sectors and so on, beyond exclusively national actors. Zomeren \& Iyer (2009) posit that a Collective action is historically defined as any action aimed at enhancing the status, power or influence of a whole community, rather than one or more individuals. However, a collective action can also seek to create or prevent group injustice.

Nowadays, there are more focused social movement studies on contexts of politics, democracy, climate change, and the environment, human rights, poverty and justice, and so on. For example, Gerbaudo (2017) conducted a study entitled "The Indignant Citizen: AntiAusterity Movements in Southern Europe and the Anti-Oligarchic Reclaiming of Citizenship". Reuben-Shemia (2017) conducted a study about "Power and Social Change: The Case of the European Social Justice Movement". Guzman-Concha (2015) conducted a study on "Radical Social Movements in Western Europe: A Configurational Analysis". Kluttz \& Walter (2018)) conducted a study on "Conceptualizing Learning in the Climate Justice Movement". Vu (2017) conducted a study on "Grassroots Environmental Activism in an Authoritarian Context: The Trees Movement in Vietnam". Koukouzelis (2017) conducted a study on Climate Change Social Movements and Cosmopolitanism, and Istrate \& Horeaserban (2018) conducted a study on "The Dynamics of Poverty and its Consequences on Regional Inequalities in Romania". However, studies that examine social movements in the context of disasters, especially those describing maps, phases, and dynamics of the social movements have not been widely carried out.

Lapindo mudflow disaster on May 29, 2006, have already been affecting people and the environment in Sidoarjo Regency, East Java Province, Indonesia, particularly in three districts which were included in the map of the affected areas, namely: Porong, Tanggulangin and Jabon. Lapindo mudflow disaster has destroyed 16 villages, comprising 1,071 acres of land that consists of agricultural, aqua-cultural, industrial, and residential areas; these areas had to be vacated because they were either drowned by the mudflows or declared to be no longer habitable.

More than 15,788 households or 48,983 people had to move from their houses to a new 
place (Sukmana, 2017). The Lapindo mudflow disaster victims then carried out a social movement as a form of protest to the government and related corporations. The social movement action of the Lapindo mudflow disaster victims lasted until 2016.

The social movement carried out by the Lapindo mudflow disaster victims was an exhibition of the social power against the political power and corporate power in a form of domination and hegemony. The Lapindo mudflow disaster occurred as the political policy of Indonesian government gave a permit to the corporation (Lapindo Brantas Inc.; PT LBI) to explore oil and gas in Porong Sub-district, Sidoarjo Regency, East Java. This policy actually breached the Regional Legislation of Sidoarjo Regency and East Java Province regarding Spatial Zoning Plan in Sidoarjo. Consequently, the Lapindo mudflow disaster victims were treated unfairly by the government and corporation (Lapindo Brantas Inc.). Hence, the Lapindo mudflow disaster victims established collective power and social movement against the political and corporate domination of government regarding oil and gas exploration policy in Porong, Sidoarjo Regency. Some forms of collective actions of the Lapindo mud disaster victims are shown in Table 1 below:

Table 1. Collective Action Events Lapindo Mud Disaster Victims in Sidoarjo

\begin{tabular}{ccl}
\hline Year & $\begin{array}{c}\text { Total of Collective } \\
\text { Action }\end{array}$ & \multicolumn{1}{c}{ Form of Collective Action } \\
\hline 2011 & 5 & $\begin{array}{l}\text { Mass Protest, Mass demonstration } \\
\text { Mass Protests, Mass demonstrations, blockades, } \\
\text { lobbies, hostage actions, acts of dzikir \& tahlilan, } \\
\text { actions to occupy the office. } \\
\text { Mass protest, mass demonstration, blockades, } \\
\text { lobbies. } \\
2012\end{array}$ \\
2013 & 18 & $\begin{array}{l}\text { Mass protest, theatrical action, demonstration. } \\
\text { Mass protest, mass demonstration, blockades, } \\
\text { lobbies. }\end{array}$ \\
\hline 2014 & 22 & \\
\hline Total & 140 & \\
\hline
\end{tabular}

Source: Data on research results in 2016

This study aims to describe the phases and dynamics of the process of the occurrence of the social movements carried out by the victims of the Lapindo mudflow disaster in Sidoarjo, East Java province, Indonesia. The contribution of the results of this study in the context of social movements is to provide an overview of the portraits of the social movements in disaster settings, how disaster victims in helpless conditions are then able to organize themselves in building forces to fight the dominance of government and corporations.

\section{Review of Literature}

\subsection{Phases of Social Movement}

Researchers have identified four phases or stages in the life of typical social movements (Macionis, 2008), namely: (1) Stages of emergence; social movements are driven by the perception that everything is not well; (2) Stages of coalescence; after emergence, social movements must define themselves and develop a 'going public' strategy; Leaders need to define policies, determine tactics, build morals, and recruit new members. The movement will at this point participate in collective acts such as marches or protests to draw. The 
movement may also form alliances with other organizations to gain necessary resources; (3) Bureaucratic stages; a social movement must take on bureaucratic characteristics to become a political power. Thus, as it is formed, the social movement depends less on a few leaders' charisma and talents, and relies more on a capable workforce. If social movements do not develop themselves in this way, they risk dissolving; and (4) period of decline; the majority of social movements ultimately lose their influence.

There are five reasons why social movement loses its influence (Macionis, 2008), namely: First, if members have met their goals, the decline may simply be a sign of success; Second, because of organizational factors such as poor leadership, loss of interest among members, insufficient funds, or government repression, a social movement can flag. Some people lose interest when the stimulus comes. Some people lose interest as everyday routine replaces the enthusiasm of early endeavours. Another common problem is instability due to internal disputes over objectives and strategies; Third, a social movement will fall apart if the existing power system diverts members from their objectives by promises of money, recognition and other incentives. Co-optation — that is, "selling out "— is one facet of the iron oligarchy law in which organizational leaders use their positions to enrich themselves; Fourth, because of repression, a social movement can collapse. Officials can kill a social movement by scaring off supporters, intimidating new recruits and even imprisoning leaders; and Fifthly, the explanation for the decline is that a social movement will "go mainstream" Some movements usually become an accepted part of the system after realizing some of their goals-so they don't contest the status quo any more.

Social Catagories Theory, that is even though modern society is haterogeneous but people who have the same nature will choose communication messages that are approximately the same and will give approximately the same response. Social Relationship Theory, that is even though communication messages only arrive at someone but if someone is as an opinion leader, then the message content information as will be forwarded to other people also interpret it. It means that the opinion leader had a personal influence which is an important mechanism that can change communication messages. (Sutarno, 2019)

According to Hiller (1975) from various results of the previous studies about social movements such as by Dawson and Getty, Smelser, and King`s, the process of organizing or the process of institutionalization becomes part of the stages in the process and dynamics of social movements. For example, Dawson and Getty mention the stages of a social movement including (1) preliminary stage of social unrest; (2) popular stage of collective excitement; (3) stage of a formal organization; and (4) institutionalization. Then, Smelser mentions three phases in the social movements, namely: (1) incipient; (2) enthusiastic mobilization; and (3) institutionalization and organization. While King's mentions three stages of social movements, namely: (1) incipient; (2) organizational; and (3) stable.

Social Movements: McAdam, McCarthy, and Zald Theoretical Perspective. To comprehend a dynamic social movement, the theoretical framework can be used as a basic analysis, such as the theoretical perspective developed by McAdam, McCarthy, \& Zald (2004) about three theoretical variants in social movement studies. McAdam, McCarthy, and Zald in the book entitled 'Comparative Perspective on Social Movements: Political Opportunity, Mobilizing Structure, and Cultural Framings' explain three crucial factors reviewing and analyzing the emergence of the development of the social movement. The three factors are: (1) structures of political opportunities and social movement problems (political opportunities); (2) formal or informal organization supporting an opposition or resistance (mobilizing structures); (3) collective process concerning interpretation, attribution, and social construction correlated between opportunity and action (cultural framing). 
The explanation of these three factors, namely political opportunities, mobilizing structures, and cultural framing are as follows:

Political Opportunities; The term Political Opportunity Approach is often referred to the Political Opportunity Structure or the Political Process Theory. The Political Process Theory of Social Movements was first formulated by Douglas McAdam in 1982 in a book entitled Political Process and the Development of Black Insurgency 1930-1970 ((Locher, 2002).

In some ways, the perspective of Political Process Theory has similarities with Resource Mobilization Theory. Similar to Resource Mobilization Theory, Political Process Theory focuses on factors that may enable a social movement to succeed, where political and economic factors are considered far more important than personal factors. The Political Process Theory focuses more on the factors that allow ordinary citizens to form their own social movements that are in conflict with the dominant society.

The focus of Political Process Theory is more into political connections than into material resources. Social movements are seen as political phenomena, not psychological phenomena. Social movements are seen as rational efforts of groups to obtain a sufficient influence to advance their political interests. All social movements are a struggle to resist the oppression or domination of the social and political power.

Eisinger (Wahlstrom \& Peterson, 2006), introduces the concept of the Political Opportunity Structure (POS), where today the concept of the Political Opportunity Structure is widely used by McAdam (1982) and Tarrow (1994). POS is an expression that aims to analyze the political situation which has an influence on the emergence, structure, scope and success of a social movement. Scientists use the concept of POS which can be applied generally in analyzing movements in the context of local characteristics. The structure is specific, while each location is different and varies from time to time.

McAdam (Locher, 2002), argues that one of the determinant factors that can drive the success of a social movement is political opportunities. There are two concepts in political opportunities, namely: (a) Political Opportunity: a harmony between groups with a larger political environment. the greater the group that can join in the political arena, the more likely it is to be able to make changes in the political system. The political opportunity is a very important aspect as compared to the other two factors. Movement organizations must obtain and use the political power to achieve significant results. Social movements are not a vacuum; it is a product of the social surrounding and political environment. The existence of changes in a system, will allow the emergence of a social movement; and (b) The Social System: In order to survive, social movements must be able to adapt to social and political changes in society. McAdam says that there are four dimensions of political opportunity that have a direct relationship with the social system where movements exist (Locher, 2002; McAdam et al., 2004), namely: (1) the relative openness or closure of the institutionalized political system; (2) the consistency or volatility of a wide variety of elite alignments usually underground in politics; (3) the involvement of elite allies; and (4) the capacity and tendency of the state to repress.

In explaining the opportunity or political opportunity for the birth of a social movement, Tarrow (1998) argues that in general there are two approaches that can be used to find out political opportunities that trigger social movements, namely: (1) Proximate opportunity structure; and (2) State centered opportunity structure.

First, the proximate opportunity structure. This approach emphasizes the signals received from policies in the community or from changes that occur in the resources and capacities of the community. In particular, this approach is further divided into two types, namely: (1) Policy specific opportunities; who views that the opportunity or political 
opportunity for the birth of a social movement can arise because of a government policy that is not in accordance with the aspirations of the community, or is not implemented properly by the government. Such government policies can provide opportunities for the presence of a social movement. Political opportunities can also arise as a result of the declining legitimacy of the government, or even because the legitimacy of the State is not recognized by society; in short, because the community does not recognize the legitimacy of the State; and (2) Group-specific opportunities; This approach looks at the structure of opportunities that focus on changes that occur or are experienced by certain groups, both their goals or their existence in society. These changes can also trigger the emergence of a collective action. The causes of these changes can be caused by various factors, such as politics, economics, ideology, culture, war, etc.

Second, state centered opportunity structure. This approach focuses on the state and all aspects in it which are the sources of opportunities that can be used to bring about a collective action. In particular, there are two types of state centered opportunity structure, namely (1) cross-sectional statism; in this approach, the state is considered as the arena of the competition between various social classes. Status and occurrence of political conflicts; and (2) dynamic statism focuses on how the country changes and how the changes produce or reduce political opportunities. This approach highlights the influence of the changes in a country and their influence on social movement actors. The whole political system according to Tarrow (McAdam et al., 2004) undergoes changes which in turn will change the environment of social actors who are strong enough to influence the initial steps, forms, and results of collective action.

Mobilizing Structures-McCarthy (McAdam et al., 2004) defines the concept of mobilizing structure as agreed ways to engage in a collective action which includes repertoires of certain tactics, forms of specific social movement organizations, and modular repertoires of social movements. In another sense, mobilizing structure is a structure that acts as a vehicle for mobilizing a social movement.

According to McCarthy (McAdam et al., 2004), there are four dimensions of mobilizing structure both formal and informal, where through this vehicle people move and involve themselves in collective action. The four dimensions of the mobilizing structure as illustrated in the following table:

Table 2. Dimension of Mobilizing Structure

\begin{tabular}{ccc}
\hline & Non-Movements & Movements \\
\hline \multirow{2}{*}{ Informal } & Friendship Networks; & Activist Networks; Affinity \\
& Neighborhoods; Work & Groups; Memory Communities. \\
Formal & Networks. & Churches; \\
& Unions; Professional & SMOs; Protest Committees; \\
& Associations. & Movement Schools. \\
\hline
\end{tabular}

\section{Source: McAdam et al., 2004}

Thus, referring to McCarthy's perspective as illustrated in Table 2, the dimensions of the mobilizing structure that can be used as a vehicle for resource mobilization for social movements include informal dimensions such as Activist Networks, Affinity Groups, and Memory Communities. meanwhile the formal dimensions are: Social Movement Organizations, Protest Committees, and Movement Schools.

Cultural Framing; The concept of framing used in the study of social movements derives from Goffman's ideas (Benford \& Snow, 2000). Goffman interpretes framing processes as a process used by the community to reproduce meaning. According to Eriyanto 
(2002), framing analysis is an analysis used to see how the media constructs reality. Framing analysis is also used to see how events are understood and framed by the media.

According to Benford \& Snow (2000) the concept of framing processes today develops in social sciences such as psychology, especially cognitive psychology, linguistics, and discourse analysis, communication and media studies, political science and policy studies, and sociology. In sociology, the concept of framing is specifically used in the study of social movements and collective action. Furthermore, Benford and Snow stated that social movement actors are seen as significant agents who are actively involved in the production and maintenance of meanings for constituents, antagonists, and bystanders. Social movement actors are deeply involved with the media, local government, and state, with what is called the politics of signification.

Referring to the views of Benford and Snow stating that framing helps to make an event or event have meaning and thus serves to regulate experience and guide action. Collective action framing also performs interpretive functions and understandings intended to mobilize potential followers and constituents, to mobilize audience support, and mobilize antagonists (Benford \& Snow, 2000). Thus, collective action framing is a set of actions oriented towards providing the beliefs and meanings that inspire and legitimate the activities and campaigns of the Social Movements Organization.

The cultured process of framing in social movements is related to the construction of the participant's identity. Various studies that discuss the development and identification of the concept of a collective identity have been carried out, both according to the American perspective and in Continental Europe. The initial study was carried out by Chicago School theorists who used classical views and social psychology on the development of perspectives from collective identity. For example, Blumer (Snow, Soule, \& Kriesi, 2004) argues that movements must develop esprit de cops among members through the construction of ingroup-out-group relationships, provide opportunities for formal interactions, and ritual and organizing formal ceremonies and rituals.

Johnston \& Klandermans (1995) define a collective identity as an interplay and various things produced by several individuals (or groups at a more complex level) and focus their orientation on actions and opportunities and constraints where an action occurs. There are three elements in the collective identity, namely: (1) Collective identity as a process involving cognitive definitions of goals, means, and fields of action; (2) Collective identity is a process that refers to an active network of relationships between actors who interact, communicate, influence each other, negotiate, and make decisions. The form of organization and leadership model, communication channel, and communication technology are part of the relations network; and (3) A certain level of emotional investment, which allows individuals to feel like part of a unit.

\section{Research Methods}

The approach used in this study was a qualitative approach (Denzin \& Lincoln, 2005; Yin, 2011), with case study (Creswell, 2007). According to Denzin and Guba (Salim, 2001), case study is a method with a qualitative approach. Snow and Tram (Klandermans \& Staggenborg, 2002) said that a case study is a study that focuses on empirically and analytically on a case of something. The strategy of inquiry was conducted through a simultaneous process starting from data reduction, data presentation, and drawing conclusion. A qualitative study with case study focuses on knowing diversity and particularity which found in the object of the study. Subject of study is commonly determined by purposive 
technique or judgmental sampling (Babbie, 2008; Neuman, 2007), in which all elements involving in social movement of mudflow victims in Sidoarjo as follows: (1) civic society that touched by mudflow disaster; (2) leaders of social movement for Sidoarjo mudflow victims; (3) public figures of Porong Sub-district; (4) coordinators of NGOs who caring about disaster victims; (5) representation of the Lapindo Brantas Incorporation; (6) representation of Sidoarjo Mud Disaster Management Agency; and (7) District Regional House of People's Representatives members of Sidoarjo.

The data were collected by using four main methods, namely: (1) in-depth interview, it was conducted towards several subjects by following interview guidelines; (2) observation, it aimed to observe the situation around infected areas; (3) Focus Group Discussion (FGD) was conducted with all representatives of mudflow victims involving the District Regional House of People's Representatives members of Sidoarjo, the Representation of Sidoarjo Mud Disaster Management Agency, the Representation of the Lapindo Brantas Incorporation, the government, and the Lapindo`s mudflow disaster victims; and (4) documentation was conducted to obtain the data from relevant legal document, such as Law, Presidential Decree, report of the Sidoarjo Mud Disaster Management Agency, the Lapindo Brantas Incorporation, and mass media. The data were based on the qualitative technique. Then, the stages of the analysis process refered to (Miles \& Huberman, 1994) theories, namely data reduction, data presentation, and drawing a conclusion (verification).

The data were collected by using interview, observation, FGD, and documentation. In the data reduction stage, the researcher selected and sorted the important data from the result of the interview, observation, and documentation. In the data presentation stage, the researcher presented the data in forms of narrative and table. Then, the data were designed for construction and description in composing dissertation. In the verification stage, the researcher drew the final conclusion after the data were constructed. Lastly, the final conclusion was verified by using the theoretical framework as the basis of the analysis. In this context, theoretical frameworks used were from McAdam, McCarthy, and Zald works.

\section{Results and Discussion}

\subsection{Phases and Dynamics of Social Movement of Lapindo mudflow Disaster Victims}

There are three periods of the social movement for Lapindo mudflow victims, namely: (1) the emergence of pre-social movement; (2) the emergence of social movement; and (3) declining and bias phase of the social movement. The details of those phases will be described as follows, First period, the social movement of mudflow victims occurred between May 29, 2006 and April 2007. In this period, Presidential Decree No.14 April 8, 2007 was issued to clarify Lapindo mudflow problem. Moreover, this period created the initiative of the pre-social movement of Lapindo mudflow victims; Second period, the social movement of the mudflow victims occurred in between April 8, 2007 and April 2009. This period was a final preparation before the emerging social movement of the mudflow victims. The crucial moment occurred in this period was the establishment of organizations for Lapindo mudflow victims, such as the Association of Lapindo Mudflow Disaster Victims (Gabungan Korban Bencana Lumpur Lapindo; GKLL) and The Community of Renokenongo Lapindo Mudflow Disaster Victims (Paguyuban Warga Renokenongo Korban Lumpur Lapindo: Pagarekorlap); and Third period, the social movement of Lapindo mudflow disaster victims occurred in between April 3, 2009 and December 2014. In this period, the dynamic of the social movement of the Lapindo mudflow disaster victims encounter bias and declining phase. 
The dynamics of the social movement of Lapindo mudflow disaster victims can be explained in Table 3 as follow:

Table 3. Stages and Dynamics of Social Movement of Lapindo mudflow Disaster Victims Period Dynamics of Sosial Movements

\begin{tabular}{lll}
\hline $\begin{array}{l}\text { Political } \\
\text { Opportunities }\end{array}$ & Mobilizing Structure & Cultural Framing
\end{tabular}

\begin{tabular}{|c|c|c|c|}
\hline $\begin{array}{l}\text { Period I: } \\
\text { Phase of } \\
\text { Pre-Social } \\
\text { Movements }\end{array}$ & $\begin{array}{l}\text { 1. The } \\
\text { constellation of } \\
\text { government and } \\
\text { Multi-party } \\
\text { politics that } \\
\text { facilitate the } \\
\text { issuance of } \\
\text { Presidential } \\
\text { Decree No. } \\
\text { 13/2006. } \\
\text { 2. The } \\
\text { failure of the } \\
\text { government and } \\
\text { corporation (PT } \\
\text { LBI) in } \\
\text { overcoming the } \\
\text { mudflow. }\end{array}$ & $\begin{array}{l}\text { 1. Characteristically } \\
\text { sporadical with the } \\
\text { community base of } \\
\text { Neighborhood } \\
\text { association and village } \\
\text { by Self-Security (Pam- } \\
\text { Swakarsa). } \\
\text { 2. Emerging } \\
\text { advocacy of NGOs. }\end{array}$ & $\begin{array}{l}\text { Constructed by a } \\
\text { coalition of NGOs } \\
\text { as "Victims of } \\
\text { Lapindo mudflow } \\
\text { Humanity". }\end{array}$ \\
\hline $\begin{array}{l}\text { Period II: } \\
\text { Phase of } \\
\text { Social } \\
\text { Movements }\end{array}$ & $\begin{array}{l}\text { The constellation } \\
\text { of government and } \\
\text { Multi-party } \\
\text { politics that } \\
\text { facilitate The } \\
\text { issuance } \\
\text { Presidential } \\
\text { Decree No. } 14 \text { of } \\
\text { 2014. }\end{array}$ & $\begin{array}{l}\text { The formed formal } \\
\text { structure of the group } \\
\text { (organization) of the } \\
\text { Lapindo mudflow disaster } \\
\text { victims. }\end{array}$ & $\begin{array}{l}\text { The victims of the } \\
\text { Lapindo mudflow } \\
\text { disaster } \\
\text { formally referred to } \\
\text { them as "Victims of } \\
\text { Lapindo Mudflow" } \\
\text { (Lumpur Lapindo: } \\
\text { LULA). }\end{array}$ \\
\hline
\end{tabular}

\begin{tabular}{|c|c|c|c|}
\hline Period III: & The issuance of the & The dynamics of relations & Not call as \\
\hline Phase of & Supreme Court of & network among the group & "Victims of \\
\hline Social & Cassation Decision & leader and the corporations & Lapindo \\
\hline Movements & & (PT LBI) that caused the & Mudflow \\
\hline Declining & $\begin{array}{l}\text { The government } \\
\text { and the }\end{array}$ & name change and strategy & Disaster" \\
\hline & corporation (PT & group Lapindo mudflow & (Lumpur \\
\hline & LBI) decide not & & $\begin{array}{l}\text { Lapindo: LULA) } \\
\text { but as "Victims }\end{array}$ \\
\hline & guilty. & & of Sidoarjo \\
\hline & & & Mudflow \\
\hline & & & Disaster" \\
\hline & & & (Lumpur \\
\hline & & & Sidoarjo: LUSI). \\
\hline
\end{tabular}




$2 . \quad$ Bias
framing in the
media between
"LULA" vs.
"LUSI".

The first period is the emergence of the pre-social movement initiative of Lapindo mudflow victims. The political opportunity factor initiated by the social movement was due to disappointment and distrust of mudflow victims towards government and PT LBI roles in handling Lapindo problems. Moreover, the victims felt an unfair treatment towards responses and policies made by government and corporation (PT LBI) regarding the evacuation process.

Generating structures was still on process sporadically and locally with civic society community posts, such as neighborhood (Rukun Tetangga: RT) and village due to the social movement of Lapindo mudflow disaster victims was unformed. In this period, personal awareness were not demonstrated by the civil society at the time, hence they should have organize the system to construct collective power for a better life. In this phase, the collective action conducted by Lapindo mudflow disaster victims was: (1) demanding to prevent mudflow coming into settlement areas; (2) demanding the compensation fee for the amount of land and property assets destroyed by mudflow; and (3) demanding the legal guarantees regarding compensation process. Mobilizing structures of this period was supported by the alliance of NGOs incorporated with Advocacy Team of Lapindo Mudflow Disaster Victims Humanity. The establishment of the advocacy team was aimed to claim to the court over an act against law conducted by government and corporation (PT LBI).

The Lapindo mudflow victims explicitly did not mention and feel that as true victims. Thus, cultural framing process couldn't be pursued. However, this process was provoked by interveners, such as Advocacy Team of Lapindo Mudflow Disaster Victims Humanity generated by Foundation of the Indonesian Legal Aid Institute (YLBHI) and Foundation of Indonesian Forum for The Environment (LSM Walhi).

The second period was the emergence of social movement initiative of the Lapindo mudflow disaster victims. The political opportunity factor marked by Presidential Decree No.14 Year 2007 regarding the preventive policy of mudflow disaster. Mainly, the victims were dissatisfied and felt unfairly treated by Presidential Decree No.14 Year 2007 substances. One of them was the management of negotiation between the Lapindo mudflow disaster victims and corporation (PT LBI).

In the negotiation process, the Lapindo mudflow disaster victims were assumed as sellers of land and property assets damaged by the mudflow disaster which was proved by land certificate and Building Construction Permit Procedures (Ijin Mendirikan Bangunan; IMB). The corporation (PT LBI) was assumed as a buyer.

Mobilizing structures were marked by the establishment of organizations for Lapindo mudflow victims, such as the Association of Lapindo Mudflow Disaster Victims (GKLL) and the Community of Renokenongo Lapindo Mudflow Disaster Victims. The emergence of such an organization was due to disappointment and distrust of mudflow victims towards government, corporation (PT LBI), and NGOs. Through confrontative action strategy, the victims demanded two things, those were (1) legal evidence instead of certificate and Building Construction Permit Procedures (Ijin Mendirikan Bangunan; IMB) in the negotiation process; and (2) payment mechanism of the negotiation process. 
In the cultural framing process, meanwhile, Lapindo victims claim that 'Lapindo Mudflow Disaster Victims' were recorded as true victims officially. It was shown by symbols, pictures, and conditions as the Lapindo mudflow victims.

The third period is declining of social movement performances for Lapindo mudflow victims. In this period, the political opportunity factor caused the decline due to the decision of the appeal to Supreme Court (Mahkamah Agung; MA) which stated that the mudflow in Sidoarjo was a pure disaster and both government and Lapindo Brantas Inc. (PT LBI) were stated not guilty. This policy was a final decision with permanent legal force (inkracht).

Moreover, this period caused the change of mobilizing structure for the Lapindo mudflow victims which were identified with the existence of such organizations. Officially, the organizations' names were changed by removing 'Lapindo Mudflow' term; "the Association of Lapindo Mudflow Disaster Victims" was to "the Association of Mudflow Victims', and "the Community of Renokenongo Lapindo Mudflow Disaster Victims" was changed to "the Community of Renokenongo Rejecting Contract". Consequently, all confrontative organizations changed to the cooperative organizations. The decline of the social movement power for Lapindo mudflow disaster victims were recognized through the political exchange between the leaders of social movement and the corporation (PT LBI). As results, the change of organizations' names and strategy would produce political and business advantages to them.

Regarding cultural framing process, this period formally affirmed that the victims were not caused or harmed by Lapindo corporations anymore. It was shown by the absence of 'Lapindo Mudflow' term. Moreover, there was a framing bias process which was identified by the emergence of the cultural framing battle in mass media between "Lapindo Mudflow" (Lumpur Lapindo; Lula) and 'Sidoarjo Mudflow (Lumpur Sidoarjo; Lusi) terms. the cultural framing as the disaster victims of "Lapindo Mudflow" (Lumpur Lapindo) was reduced to disaster victims of Sidoarjo Mudflow (Lumpur Sidoarjo). In short, the corporations (Lapindo Brantas Inc.; PT LBI) were received an advantage in the political opportunity, mobilizing structure, and cultural framing aspects.

Particularly, the social movement for the Lapindo mudflow victims emerged due to NGOs initiatives and roles. However, these initiatives and roles did not work, then created distrust towards the NGOs. The Lapindo mudflow victims established a social movement to demand remedies or compensations over their land and property assets after the mudflow. In the next phase, the social movement declined in authority aspect due to the differences of interest among organization leaders and then caused friction and cooptation among the social movement organizations of the Lapindo mudflow victims coming from political power and corporation.

\section{Conclusion}

The mapping on the phases and dynamics of the social movements of the Lapindo mudflow disaster victims has been done successfully. The study indicates that social movements of Lapindo mudflow disaster victims are mapped into three phases: (1) the period of the emergence of ideas pre-social movements; (2) the period of stabilization and consolidation of social movements; and (3) the period of decline of social movements. The dynamics of social movements of Lapindo mudflow are based on three aspects: (1) political opportunity; (2) mobilizing structure, and (3) cultural framings.

The results of this study indicate that in the context of the case of the social movement of the Lapindo mudflow disaster victims, if analyzed through the perspectives of McAdam, 
McCarthy's and Zald's theoretical framework involving three aspects, namely political opportunity, mobilizing structure, and cultural framings, the phase and dynamics of social movements different from Macionis, Dawson and Getty, Smelser, and King's perspectives. Macionis states that the phase of social movements blows emergence stages, coalescence stages; bureaucratic stages, and decline stage. Dawson and Getty mention the stages of a social movement including the preliminary stage of social unrest, popular stage of collective excitement, stage of formal organization, and institutionalization. Then, Smelser mentions three phases in social movements, namely incipient, enthusiastic mobilization; and institutionalization and organization. While King's mentions three stages of social movements, namely, incipient, organizational, and stable.

\section{References}

Babbie, E. (2008). The Basic of Social Research (Vol. 91). Belmont: Wadsworth.

Benford, R. D., \& Snow, D. A. (2000). Framing Processes and Social Movements: An Overview and Assessment. Annual Review of Sociology, 26(1), 611-639. https://doi.org/10.1146/annurev.soc.26.1.611

Budi, F. H. (2009). Bisnis dan Demokrasi. Malang: Averroes Press.

Creswell, J. W. (2007). Qualitative Inqquiry and Research Design: Chosing Among Five Approaches. Thousand Oaks: SAGE Publications. https://doi.org/10.1111/14679299.00177

Damsar. (2010). Pengantar Sosiologi Politik. Jakarta: Prenada Media Group.

Denzin, N. K., \& Lincoln, Y. S. (2005). The Sage Handbook of Qualitative Research. (N. K. Denzin \& Y. S. Lincoln, Eds.). California.

Eriyanto. (2002). Analisis Framing: Konstruksi, Ideologi, dan Politik Media. Yogyakarta: LKiS.

Fakih, M. (2010). Masyarakat Sipil untuk Transformasi Sosial: Pergolakan Ideologi LSM Indonesia. Yogyakarta: Insist Press.

Gerbaudo, P. (2017). The indignant citizen : anti-austerity movements in southern Europe and the anti-oligarchic reclaiming of citizenship, 16(1), 36-50.

Guzman-Concha, C. (2015). Radical Social Movements in Western Europe: A Configurational Analysis, 14(6), 668-69

Hiller, H. H. (1975). A Reconceptualization of the Dynamics of Social Movement Development. The Pacific Sociological Review, 18, 342-360.

Istrate, M., \& Horea-serban, R. I. (2018). The dynamics of poverty and its consequences on regional inequalities in Romania, 9(1), 63-87.

Johnston, H., \& Klandermans, \& B. (1995). Social Movements and Culture.

Klandermans, B., \& Staggenborg, S. (2002). Methods of Social Movement Research. Minneapolis: the University of Minnesota Press.

Kluttz, J., \& Walter, P. (2018). Conceptualizing Learning in the Climate Justice Movement. https://doi.org/10.1177/0741713617751043

Koukouzelis, K. (2017). Climate Change Social Movements and Cosmopolitanism, 14(5), 746-761.

Locher, D. A. (2002). Collective Behavior.pdf. New Jersey: Prentice Hall.

Macionis, J. J. (2008). Sociology. New Jersey: Prentice Hall.

McAdam, D., McCarthy, J. D., \& Zald, M. N. (2004). Comparative Perspectivees on Social Movements: Political Opportunity, Mobilizing Structures, and Cultural Framing. Cambridge: Pearson Education, Inc.

Miles, M. B., \& Huberman, A. M. (1994). Qualitative Data Analysis. Thousand Oaks. 
Neuman, W. L. (2007). Basic of Social Research: Qualitative and Quantitatitve Approaches. Quah, S. R., \& Sales, A. (2000). The International Handbook of SOCIOLOGY. London.

Reuben-Shemia, D. A. (2017). Power and Social Change: The case of the European social justice movement, 36(4), 51-60.

Salim, A. (2001). Teori dan Paradigma Penelitan Sosial: Pemikiran Norman K. Denzin \& Egon Guba, dan penerapannya. Yogyakarta: Tiara Wacana.

Singh, R. (2001). Social Movements, Old and New: A Post-Modernist Critique. New Delhi: SAGE publications India, Ltd.

Snow, D. A., Soule, S. A., \& Kriesi, H. (2004). The Blackwell Companion to Social Movements. Oxford: Blackwell Publishing. https://doi.org/10.1002/9780470999103

Sukmana, O. (2017). Konflik Horisontal Antar Kelompok Korban Bencana Lumpur Lapindo. Jurnal Sosial Politik, 3(1), 78-98. https://doi.org/10.22219/SOSPOL.V3I1.4402.G4683

Sutarno. (2019). Political Imaging Techniques Carried Out by Baitul Muslimin Indonesia (BAMUSI) in Increasing Public Political Support for PDI Perjuangan Medan City. Budapest International Research and Critics Institute-Journal (BIRCI-Journal). P. 164174.

Tarrow, S. (1998). Power in Movements: Social Movements and Contentious Politics. New York: Cambridge University Press.

Tarrow, S. (2008). Charles Tilly and the Practice of Contentious Politics Charles Tilly and the Practice of Contentious Politics. Social Movement Studies: Journal of Social, Cultural and Political Protest, (May 2012), 37-41. https://doi.org/10.1080/14742830802485601

Triwibowo, D. (2006). Gerakan Sosial: Wahana Civil Society bagi Demokratisasi. Jakarta: LP3ES.

$\mathrm{Vu}$, N. A. (2017). Grassroots Environmental Activism in an Authoritarian Context: The Trees Movement, 1180-1208. https://doi.org/10.1007/s11266-017-9829-1

Wahlstrom, M., \& Peterson, A. (2006). Between the State and the Market Expanding the Concepts of "Political Opportunity Structure". Acta Sociological, 49.

Yin, R. K. (2011). Qulaitative Research From Start to Finish. New York.

Zomeren, M. Van, \& Iyer, A. (2009). Introduction to the Social and Psychological Dynamics of Collective Action. Journal of Social Issues, 65(4), 645-660. 